\title{
Characterization of a possible uptake mechanism of selective antibacterial peptides
}

\author{
Carlos Polanco ${ }^{1,2}{ }^{\boxplus}$, José Lino Samaniego $0^{1,2}$, Jorge Alberto Castañón-González1, \\ Thomas Buhse ${ }^{3}$ and Marili Leopold Sordo ${ }^{1}$
}

1Facultad de Ciencias de la Salud, Universidad Anáhuac, Huixquilucan Estado de México, México; ${ }^{2}$ Departamento de Matemáticas, Facultad de Ciencias, Universidad Nacional Autónoma de México, México; ${ }^{3}$ Centro de Investigaciones Químicas, Universidad Autónoma del Estado de Morelos, Cuernavaca Morelos, México

Selective antibacterial peptides containing less than 30 amino acid residues, cationic, with amphipathic properties, have been the subject of several studies due to their active participation and beneficial effects in strengthening the immune system of all living organisms. This manuscript reports the results of a comparison between the group of selective antibacterial peptides and another group called "cell penetrating peptides". An important number of the selective antibacterial peptides are cell penetrating peptides, suggesting that their toxicity is related to their uptake mechanism. The verification of this observation also includes the adaptation of a method previously published, called Polarity index, which reproduces and confirms the action of this new set of peptides. The efficiency of this method was verified based on four different databases, yielding a high score. The verification was based exclusively on the peptides already reported in the databases which have been experimentally verified.

Key words: Polarity index method; cell penetrating peptides; selective antibacterial peptides

Received: 16 August, 2013; revised: 17 October, 2013; accepted: 19 December, 2013; available on-line: 28 December, 2013

\section{INTRODUCTION}

Selective cationic amphipathic antibacterial peptides (SCAAP) (Del Rio et al., 2001; Juretić et al., 2009) feature very high toxicity towards bacteria and a minimal toxicity towards mammalian cells. Although so far the reason for this selective toxicity is not known, it makes them potentially important for the production of drugs for the pharmaceutical industry. SCAAP were initially isolated in living organisms and then tested experimentally in laboratory, but after a few decades the number of SCAAP was reduced exponentially; therefore, new bioinformatics tools had to be used to build them synthetically. This work uses the 30 SCAAP reported by Del Rio et al. (Del Rio et al., 2001) that recently this research group was able to identify through a method called Polarity index (Polanco et al., 2012; Polanco et al., 2013), showing a high discriminative efficiency measuring a single physicochemical property, polarity (or electronegativity), which informs of the electromagnetic balance of the peptide.

Parallel to these works, several research groups have studied some peptides called Cell Penetrating Peptides (CPP) characterized by being short, between 10 and 30 amino acids in length, and penetrating the cell membrane without displaying any specificity (Gautam et al.,
2012), which makes them excellent candidates for Trojan peptides (Derossi et al., 1998). Trojan peptides are a union of two or more peptides with different characteristics that together make a peptide with certain desirable features; they are usually used as internment peptides in pathogenic organisms.

In recent years, with the complete information provided by the CPPsite database (Gautam et al., 2012), the study of CPP was encouraged making it possible to compare them with other peptide groups and increase the understanding of these fundamental functional units. This work derived from the compilation of this information, since it allowed us to study the relationship between CPP and SCAAP, finding that the CPP with non-endocytic pathway uptake mechanism exhibit a high correlation with SCAAP, particularly with the SCAAP set from Del Río et al. (Del Rio et al. 2001). This led us to define the group studied here as SCAAP-CPP, whose first property is to belong to both groups.

According to the definition of the SCAAP-CPP set, this work was mainly aimed to find the correlation in the sequences of both groups and to analyze the pattern found in their polarity matrix (Polanco et al., 2013) with the Polarity index method (Polanco et al., 2012). The method testing to identify SCAAP-CPP was exhaustive, as four databases were inspected: APD2 (Wang \& Wang, 2009), CPPsite (Gautam et al., 2012), AVPpred (Thakur et al., 2012) and Uniprot (Magrane \& Uniprot, 2011), finding that the efficiency of the SCAAP-CPP identification is remarkably high.

\section{MATERIALS AND METHODS}

Polarity index method description. Polarity index method is a supervised type mathematical algorithm (Jones \& Sivaloganathan, 2011), that carries out an extensive analysis of the physico-chemical property polarity; although there are multiple algorithms evaluating this property on its own or in combination with other properties, this particular algorithm expresses polarity using a fourth order square matrix (16 items representing the four polar groups with 16 possible polar interactions $\mathrm{P}$ $+, \mathrm{P}-, \mathrm{N}, \mathrm{NP})$, allowing observation of all possible polar interactions that can be extracted from the peptide linear sequence, reading it from left to right by pairs. For instance if we have the following sequence: HTWT

e-mail: polanco@unam.mx

Abbreviations: CPP, cell penetrating peptides; SCAAP, Selective cationic amphipathic antibacterial peptides 
Table 1. Polarity matrix.

\begin{tabular}{ccccc}
\hline & $\mathrm{P}_{+}$ & $\mathrm{P}-$ & $\mathrm{N}$ & $\mathrm{NP}$ \\
\hline $\mathrm{P}+$ & 1 & 3 & 6 & 4 \\
\hdashline $\mathrm{P}-$ & 2 & 1 & 4 & 1 \\
\hline $\mathrm{N}$ & 7 & 3 & 7 & 10 \\
\hdashline $\mathrm{NP}$ & 3 & 1 & 10 & 7 \\
\hline
\end{tabular}

Polarity matrix interaction in the polarity groups differentiated by their lateral chain to the sequence e.g. HTWTWTPICKSRSHEYKG RCIQDMDCNAACVKESESYTGGFCNGRPPFKQCFCTKPCKRRAAATLRWPGW.

WTP ICKSR SHEY KGR CIQDM DC NAACV KESE SYTG GFC NGRP PFKQC FCTKP CKRR AAATL RW PGW, according to the numerical assignation by polar group, its equivalent would be: 1343434431313 122131343242334434123232333433314441334 3314311214443414434 (Polanco et al., 2012, Table 1). The matrix is created when reading the latter as indicated and the incidences are counted as shown in Table 2. This method differs from others by considering 16 metrics that make the information more extensive.

As the method has been already published (Polanco et al., 2012), we will only point out the changes required to identify SCAAP-CPP (see Supplementary Material section). In this case the test plan was focused on two aspects: (a) to verify the SCAAP and CPP matches located in the databases and (b) to particularly identify the SCAAP-CPP using Polarity index method.

Polarity index method updates. Modifications to the source program. The $\mathrm{Q}[i, j]$ matrix in the source program (Polanco et al., 2012) was substituted with Table 2, which is the entire peptide set of cell penetrating sequences with unique pathogenic action. Once $\mathrm{Q}\left[i_{j}\right]$ polarity matrix was finished, it was normalized to one. Under this rule we considered the cell penetrating peptides non-endocytic pathway type, taken from the CPPsite database (Gautam et al., 2012). It is important to emphasize that we did not use the SCAAP group, or the union of SCAAP and CPP groups.

The rule in the source program (Polanco et al., 2012) was substituted with the $\mathrm{P}[i, j]+\mathrm{Q}[i, j]$ vector complying with the next rule: polar interaction 11 is present in the $7^{\text {th }}$ position (Table 3).

APD2 database data preparation. From all 3636 peptides in APD2 database studied and classified we found the following with multiple action on: 149 GramONLY, 1711 Gram+/Gram-ONLY, 315 Gram+ONLY, 141 cancer cells, 9 sperms, 88 HIV, 744 fungi, 21 insects, 244 mammalian cells, 47 parasites, 3 protists, 39 chemotaxis, 0 SCAAP, 125 virus; and 1059 peptides with single action on: 111 Gram-ONLY, 213 Gram+ONLY, $518 \mathrm{Gram}+/ \mathrm{Gram}-\mathrm{ONLY}, 20$ cancer cells, $0 \mathrm{HIV}, 88$ fungi, 35 H1N1, 2 insects, 11 mammalian cells, 9 parasites, 1 protists, 0 chemotaxis, 30 SCAAP, 0 sperms and 21 virus. Multiple action peptide refers to action against

Table 2. $Q[i, j]$ Polarity matrix

\begin{tabular}{lllll}
\hline & $\mathrm{P}+$ & $\mathrm{P}-$ & $\mathrm{N}$ & $\mathrm{NP}$ \\
\hline $\mathrm{P}+$ & 0.1299774647 & 0.0045078886 & 0.0503380932 & 0.1502629668 \\
\hdashline $\mathrm{P}$ & 0.0060105184 & 0.0000000000 & 0.0007513148 & 0.0075131478 \\
\hdashline $\mathrm{N}$ & 0.0548459813 & 0.0030052592 & 0.0435762592 & 0.0555972941 \\
\hdashline NP & 0.1359879822 & 0.0075131478 & 0.0653643906 & 0.2148760259 \\
\hline
\end{tabular}

93 incidences of cell penetrating peptides of non-endocytic pathway type, taken from CPPsite database (Gautam et al., 2012). several pathogens whereas single action peptide refers to action against one pathogen agent.

AVPpred database data preparation. 60 antiviral peptides were studied from the AVPpred database (Thakur et al., 2012).

CPPsite database data preparation. 520 cell penetrating peptides were classified from CPPsite database (Gautam et al., 2012) by their uptake mechanism as follows: 93 non-endocytic pathway, 22 endocytic pathway, and 405 of unknown pathway. Those peptides with different penetration mechanism included in CPPsite database were not considered.

SCAAP data preparation. The 30 SCAAP studied by Del Rio et al. were used (Del Rio et al., 2001, Table 2 and Table 2A).

Uniprot database data preparation. 60 antiviral peptides were extracted from Uniprot Database (Magrane \& Uniprot, 2011).

\section{RESULTS}

Polarity index method is an algorithm that determines the probable SCAAP-CPP non-endocytic pathway candidates, by using their polarity sequence. We applied the method to get the set of 30 SCAAP from the four databases mentioned, with the following results:

(i) Polarity index method excluded 2 peptides from the 30 SCAAP candidates from Del Rio et al. (Del Rio et al., 2001) (Table 4, entries \#9 and 21 with symbol -), these peptides have very different TI but the same sequence, it showed (11/13) 55\% efficiency detecting SCAAP-CPP (Table 5).

(ii) It also excluded the 13 sub-classifications in APD2 (Table 5, columns: Gram+ONLY, Gram-ONLY, Gram+/Gram-, fungi, protists, parasites, insects, cancer cells, mammalian cells, virus, SCAAP, and chemotaxis, in blue), the classification in AVPprep (Table 5, in green), the sub-classification in Uniprot (Table 5, in red), and three sub-classifications in CPPsite (Table 5, in black).

(iii) Polarity index method also identified three SCAAP-CPP peptides (Table 4, entries \#2, 4, and 5), whose experimental attributes are SCAAP and CPP simultaneously. Note that those SCAAP were not located in the CPP database.

\section{DISCUSSION}

The increasing number of pathogens resistant to multiple drugs that have been registered in the last 20 years (Rana, 2011), and the decrease in the number of effective antibacterial drugs, indicate that by the end of this decade there will be few antimicrobial drugs available for human population. There are no "magic bullets"; in fact, the possibility of losing the current antibacterial arsenal is more likely every day unless we reverse this trend. Bearing in mind that $67 \%$ of natural origin antibiotics (Donadio et al., 2010) in clinical development are researched in small pharmaceutical companies with limited budgets, and as the major pharmaceutical companies focus their efforts on developing new antibacterial agents, we gather that only with a multidisciplinary strategy with novel bioinformatics algorithms acting as "first filter" in experimental tests, we will be able to face this real threat. The SCAAP-CPP is an antibacterial group with potential for the de- 
Table 3. Polarity index method test.

\begin{tabular}{|c|c|c|c|c|c|c|c|c|c|c|c|c|c|c|c|c|}
\hline Position & 1 & 2 & 3 & 4 & 5 & 6 & 7 & 8 & 9 & 10 & 11 & 12 & 13 & 14 & 15 & 16 \\
\hline $\mathrm{P}[i, j]+\mathrm{Q}[i, j]$ vector of study & $(1,1)$ & $(1,2)$ & $(1,3)$ & $(1,4)$ & $(2,1)$ & $(2,2)$ & $(2,3)$ & $(2,4)$ & $(3,1)$ & $(3,2)$ & $(3,3)$ & $(3,4)$ & $(4,1)$ & $(4,2)$ & $(4,3)$ & $(4,4)$ \\
\hline $\begin{array}{l}\text { Rule \# } 1 \\
\text { Polar interaction } 11 \text { is } \\
\text { present at the } 7^{\text {th }} \text { position }\end{array}$ & & & & & & & $\checkmark$ & & & & & & & & & \\
\hline
\end{tabular}

Polarity index method identification rule for SCAAP-CPP. ( $\checkmark$ ): Polar interaction present at the position. (x): Polar interaction not present at the position.

velopment of new drugs due to their cellular penetration. The use of CPP as peptide vectors for delivering therapeutic agents without side effects has been demonstrated (Chugh \& Eudes, 2008) and according to our results, the matching SCAAP with the same properties that CPP are very high. Polarity index method (Polanco et al., 2012) was initially used in the detection of SCAAP but a variation on the method (Polanco et al., 2013) showed a positive identification of SCAAP-CPP with a high level of reliability $(85 \%)$, as this group of peptides has proven affinity for bacterial membrane.
Polarity index method exhibits four important characteristics: (i) it uses a single physicochemical property: polarity, which is an effective SCAAP-CPP discriminator, (ii) it only uses the peptide linear sequence to identify the main pathogenic action, (iii) it determines a comprehensive profile of the peptide polar dynamics, as it considers 16 possible polar interactions and (iv) the polarity matrix is differentially weighted, thereby strengthening the SCAAP profile and minimizing false positives. The versatility of the method allows minimal changes to achieve the identification of other pathogenic groups.

Table 4. Polarity index matches by linear sequence in cell penetrating peptides.

\begin{tabular}{|c|c|c|c|c|c|c|c|c|c|}
\hline Entry & Pubmed & Source organism & Peptide sequence & Gram (-) & Gram (+) & $\mathrm{TI}$ & CPP & $\begin{array}{l}\text { Polarity } \\
\text { Index }\end{array}$ & Reference \\
\hline 1 & 9923682 & (KLAKKLA)2-NH2 & KIAKKIAKIAKKIA & 6 & 6 & 45.3 & & & (Alm et al., 1999) \\
\hline 2 & 16077101 & (KIAKKIA)3-NH2 & KIAKKIAKIAKKIAKIAKKIA & 4 & 4 & 2.8 & & - & (Vasconcelos et al., 2005) \\
\hline 3 & & (KIAKLAK)2-NH2 & KIAKLAKKIAKLAK & 6 & 6 & 86.2 & & & (Javadpour et al., 1996) \\
\hline 4 & 16077101 & (KIAKLAK)3NH2 & KIAKLAKKIAKLAKKIAKLAK & 4 & 4 & 2.3 & & - & (Vasconcelos et al., 2005) \\
\hline 5 & 8905231 & (KALKALK)3-NH2 & KALKALKKALKALKKALKALK & 4 & 8 & 2.8 & & $\bullet$ & (Kaneko et al., 1996) \\
\hline 6 & & (KLGKKLG)3-NH2 & KLGKKLGKLGKKLGKLGKKLG & 4 & 4 & 98.3 & & & (Javadpour et al., 1996) \\
\hline 7 & 1711035 & Cecropin-A & $\begin{array}{l}\text { KWKLFKKIEKVGQNIRDGIIKAGPAVAVVGQA- } \\
\text { TQIAK }\end{array}$ & 0.2 & $>300$ & 1000 & & & (Gudmundsson et al., 1991) \\
\hline 8 & 6309516 & Melittin & GIGAVLKVLTTGLPALISWIKRKRQQ & 0.8 & $>0.2$ & 500 & & & (Vlasak et al., 1983) \\
\hline 9 & 2833514 & Magainin-2 & GIGKFLHSAKKFGKAFVGEIMNS & 4 & 300 & 75 & $\bullet$ & & (Terry et al., 1998) \\
\hline 10 & 1711035 & $\mathrm{CA}(1-13) \mathrm{M}(1-13)-\mathrm{NH} 2$ & KWKLFKKIEKVGQGIGAVLKVLTTGL & 55 & 0.5 & 400 & & & (Gudmundsson et al., 1991) \\
\hline 11 & 6309516 & $\mathrm{CA}(1-8) \mathrm{M}(1-18)-\mathrm{NH} 2$ & KWKLFKKIGIGAVLKVLTTGLPALIS & 63 & 0.3 & 2000 & & & (Wood \& Matson, 1989) \\
\hline 12 & 2542273 & Kla1 & KLALKLALKAWKAALKLA & 2.6 & 11 & 2.1 & - & - & (Wood \& Matson, 1989) \\
\hline 13 & & $\mathrm{Kla} 2$ & KLALKAALKAWKAAAKLA & 45 & 107 & 9.7 & - & - & (Mor et al., 1994) \\
\hline 14 & 15001715 & Kla3 & KLALKAAAKAWKAAAKAA & $>91$ & $>200$ & 2.2 & - & $\bullet$ & (Dietrich et al., 1994) \\
\hline 15 & 9389475 & Kla7 & KAIAKSILKWIKSIAKAI & 1.4 & 1.8 & 0.3 & & & (Klenk et al., 1997) \\
\hline 16 & 1689726 & Kla8 & KALAALLKKWAKLLAALK & 3 & 2.5 & 0.4 & $\bullet$ & $\bullet$ & (Sahr et al., 1990) \\
\hline 17 & 2974085 & Kla9 & KLLAKAALKWLLKALKAA & 1.6 & 1.7 & 0.3 & - & $\bullet$ & (Umesono et al., 1998) \\
\hline 18 & & Kla10 & KALKKLLAKWLAAAKALL & 1.5 & 2 & 0.3 & - & $\bullet$ & (Lorenz et al., 1998) \\
\hline 19 & 15229592 & Kla11 & KITLKLAIKAWKLALKAA & 5.3 & 10 & 1.9 & - & $\bullet$ & (Dujon et al., 2004) \\
\hline 20 & & Kla12 & KALAKALAKLWKALAKAA & 1.5 & 10 & 1.7 & $\bullet$ & $\bullet$ & (Lorenz et al., 1998) \\
\hline 21 & 2833514 & $\mathrm{~m} 2 \mathrm{a}$ & GIGKFLHSAKKFGKAFVGEIMNS & $>80$ & 428 & 10.7 & $\bullet$ & & (Terry et al., 1998) \\
\hline 22 & 2833514 & W16-m2a & GIGKFLHSAKKFGKAWVGEIMNS & $>80$ & 509 & 12.7 & & & (Terry et al., 1998) \\
\hline 23 & 2833514 & L2R11A20-m2a & GLGKFLHSAKRFGKAFVGEAMNS & 75 & $>75$ & 13.3 & & & (Terry et al., 1998) \\
\hline 24 & 2833514 & 16L15-m2a & GIGKFIHSAKKFGKLFVGEIMNS & 38 & 38 & 6.8 & & & (Terry et al., 1998) \\
\hline 25 & 2833514 & 16A8L15I17-m2a & GIGKFIHAAKKFGKLFIGEIMNS & 2.4 & 9.6 & 13.3 & & & (Terry et al., 1998) \\
\hline 26 & 2833514 & I6R11R14W16-m2a & GIGKFIHSAKRFGRAWVGEIMNS & 37.5 & $>75$ & 8.1 & & & (Terry et al., 1998) \\
\hline 27 & 2833514 & 16V9W12T15I17-m2a & GIGKFIHSVKKWGKTFIGEIMNS & 64 & 2.3 & 24.3 & & & (Terry et al., 1998) \\
\hline 28 & 2833514 & $100-\mathrm{m} 2 \mathrm{a}$ & GIAKFGKAAAHFGKKWVGELMNS & $>75$ & 700 & 9.3 & & & (Terry et al., 1998) \\
\hline 29 & 2833514 & $140-\mathrm{m} 2 \mathrm{a}$ & GIGKFLHTLKTFGKKWVGEIMNS & 13 & 35 & 2.7 & & & (Terry et al., 1998) \\
\hline 30 & 2833514 & $160-\mathrm{m} 2 \mathrm{a}$ & GIGHFLHKVKSFGKSWIGEIMNS & 76 & 82 & 4.3 & & & (Terry et al., 1998) \\
\hline
\end{tabular}

Matching sequences in both SCAAP (del Rio et al., 2001) and CPP (Gautam et al., 2012) found in APD2 (Wang \& Wang, 2009). PUBMED National Center for Biotechnology information, U.S. National Library of Medicine http://blast.ncbi.nlm.nih.gob/ accessed March 20, 2013. CPP: (๑) SCAAP matching CPP experimentally detected. Polarity Index: (-) SCAAP-CPP predicted by Polarity index; ( SCAAP candidates not matching CPP predicted by polarity index method. Tl: therapeutic index of a peptide, defined as the ratio between the inhibitory concentration observed in mammalian cells and the inhibitory concentration observed in bacterial cells (definition taken from del Rio (del Rio et al., 2001)). ( $\bullet$ Identical peptides published with different TI (del Rio et al., 2001) Gram (1)/Gram (): Minimal inhibitory concentration ( $\mu \mathrm{g} / \mathrm{mll}$ ) of peptide against Gram(1) and Gram () bacterial cells (del Rio et al., 2001), Table 2A). 
Table 5. Polarity index matches by pathogenic action.

\begin{tabular}{|c|c|c|c|c|c|c|c|c|c|c|c|}
\hline Database & APD2 & APD2 & APD2 & APD2 & APD2 & APD2 & APD2 & APD2 & APD2 & APD2 & \\
\hline $\begin{array}{l}\text { Total } \\
\text { hits }\end{array}$ & $\begin{array}{l}\text { Gram+ } \\
\text { ONLY }\end{array}$ & $\begin{array}{l}\text { Gram- } \\
\text { ONLY }\end{array}$ & $\begin{array}{l}\text { Gram+/ } \\
\text { Gram- }\end{array}$ & Fungi & Protists & Parasites & Insects & HIV & $\begin{array}{l}\text { Cancer } \\
\text { cells }\end{array}$ & $\begin{array}{l}\text { Mamma- } \\
\text { lian cells }\end{array}$ & $\%$ \\
\hline $\begin{array}{l}\text { Unique } \\
\text { action }\end{array}$ & $\begin{array}{l}11 \\
213\end{array}$ & $\begin{array}{l}16 \\
111\end{array}$ & $\begin{array}{l}53 \\
518\end{array}$ & $\begin{array}{l}3 \\
88\end{array}$ & $\begin{array}{l}0 \\
1\end{array}$ & $\begin{array}{l}0 \\
9\end{array}$ & $\begin{array}{l}0 \\
2\end{array}$ & $\begin{array}{l}0 \\
0\end{array}$ & $\begin{array}{l}0 \\
20\end{array}$ & $\begin{array}{l}1 \\
11\end{array}$ & \\
\hline $\begin{array}{l}\text { Multiple } \\
\text { action }\end{array}$ & $\begin{array}{l}19 \\
315\end{array}$ & $\begin{array}{l}18 \\
149\end{array}$ & $\begin{array}{l}179 \\
1711\end{array}$ & $\begin{array}{l}76 \\
744\end{array}$ & $\begin{array}{l}0 \\
3\end{array}$ & $\begin{array}{l}6 \\
47\end{array}$ & $\begin{array}{l}4 \\
21\end{array}$ & $\begin{array}{l}0 \\
0\end{array}$ & $\begin{array}{l}24 \\
141\end{array}$ & $\begin{array}{l}30 \\
244\end{array}$ & $<17$ \\
\hline Database & APD2 & APD2 & APD2 & Uniprot & AVPpred & CPPsite & CPPsite & CPPsite & & & \\
\hline $\begin{array}{l}\text { Total } \\
\text { hits }\end{array}$ & $\begin{array}{l}\text { Chemo- } \\
\text { taxis }\end{array}$ & Virus & Sperms & $\mathrm{H} 1 \mathrm{~N} 1$ & Virus & $\begin{array}{l}\text { CPP Non- } \\
\text {-endocytic } \\
\text { pathway }\end{array}$ & $\begin{array}{l}\text { CPP En- } \\
\text { docytic } \\
\text { pathway }\end{array}$ & $\begin{array}{l}\text { CPP } \\
\text { Unk- } \\
\text { nown } \\
\text { pathway }\end{array}$ & $\begin{array}{l}\text { Po- } \\
\text { larity } \\
\text { index } \\
\text { SCAAP }\end{array}$ & $\begin{array}{l}\text { Polarity } \\
\text { index } \\
\text { SCAAP } \\
\text { CPP }\end{array}$ & $\%$ \\
\hline $\begin{array}{l}\text { Unique } \\
\text { action }\end{array}$ & $\begin{array}{l}0 \\
0\end{array}$ & $\begin{array}{l}9 \\
60\end{array}$ & $\begin{array}{l}0 \\
0\end{array}$ & $\begin{array}{l}0 \\
35\end{array}$ & $\begin{array}{l}8 \\
60\end{array}$ & $\begin{array}{l}29 \\
93\end{array}$ & $\begin{array}{l}4 \\
22\end{array}$ & $\begin{array}{l}0 \\
0\end{array}$ & $\begin{array}{l}11 \\
30\end{array}$ & $\begin{array}{l}11 \\
13\end{array}$ & 85 \\
\hline $\begin{array}{l}\text { Multiple } \\
\text { action }\end{array}$ & $\begin{array}{l}2 \\
39\end{array}$ & $\begin{array}{l}0 \\
0\end{array}$ & $\begin{array}{l}1 \\
9\end{array}$ & $\begin{array}{l}0 \\
0\end{array}$ & $\begin{array}{l}0 \\
0\end{array}$ & $\begin{array}{l}0 \\
0\end{array}$ & $\begin{array}{l}0 \\
0\end{array}$ & $\begin{array}{l}64 \\
405\end{array}$ & $\begin{array}{l}0 \\
0\end{array}$ & $\begin{array}{l}0 \\
0\end{array}$ & $<15$ \\
\hline
\end{tabular}

Matches found by Polarity Index method in both unique and multiple action peptide groups. Unique action: Peptides with pathogenic action against only one group. Multiple action: Peptides with pathogenic action against two or more groups. (\%): Percentage hits/total peptides. Database: Name of database tested: APD2 (Wang \& Wang, 2009). CPPsite (Gautam et al., 2012). AVPpred (Thakur et al., 2012). SCAAP set studied by Del Rio et al. ( del Rio et al., 2001). Uniprot (Magrane \& Uniprot, 2011). Polarity index SCAAP: Total SCAAP identified by polarity index method. Polarity index SCAAP-CPP: Total SCAAP-CPP identified by polarity index method.

Our team has already used this method to produce an analytical classification of the APD2 database, with high efficiency results (unpublished data), indicating its potential to identify the role of a peptide.

Our group is currently working on four lines of development using this method: (i) to trace massive databases of antimicrobial peptides developing parallel versions of the source program in MPI-CUDA-F77 and MPI-CU$\mathrm{DA}-\mathrm{C}$, to be used in a computer with 4 Xeon processors in shared memory, which includes a GPU-KeplerNvidia cluster in GNU Linux environment, (ii) to design a new expression of the method rules to enable other researchers to generate their own rules and thus achieve the identification of other peptide groups, (iii) to develop a JAVA-version of the method source code and (iv) the synthesis and experimental verification of the three SCAAP-CPP candidates identified by the method (Table 5, entries: 2, 4 And 5).

\section{CONCLUSIONS}

In the SCAAP-CPP peptide group analytically identified here, toxicity correlates with the internment mechanism that penetrates the pathogen membrane, showing the relevance of crosschecking information in specialized databases at a regular basis, and to identify by other factors the peptides that are already known. Due to its high discriminative efficiency and low demand of computational resources, Polarity index method can be used as a first filter in peptide selection, reducing experimental trials in laboratory and making the procedure more practical. It can also be applied in the field of Proteomics to exhaustively analyze large groups of fixed length peptides, improving the understanding of how peptides are built in nature.

\section{Availability}

The test files and source program are given as "Supplementary Material".

\section{Conflict of Interests}

We declare that we do not have any financial and personal interest with other people or organizations that could inappropriately influence (bias) our work.

\section{Author Contributions}

Theoretical conception and design: CP. Computational performance: CP. Data analysis: CP, and JLS. Results discussion: CP, JLS, JACG, TB and MLS.

\section{Acknowledgements}

The authors wish to thank the Departamento de Cómputo, Instituto Nacional de Ciencias Médicas y Nutrición Salvador Zubirán for support, and for the proofreading of this manuscript by Concepción Celis Juárez.

\section{REFERENCES}

Alm RA, Ling LS, Moir DT, King BL, Brown ED, Doig PC, Smith DR, Noonan B, Guild BC, deJonge BL, Carmel G, Tummino PJ, Caruso A, Uria-Nickelsen M, Mills DM, Ives C, Gibson R, Merberg D, Mills SD, Jiang Q, Taylor DE, Vovis GF, Trust TJ (1999) Genomic-sequence comparison of two unrelated isolates of the human gastric pathogen Helicobacter pylori. Nature 397: 17-180.

Chugh A, Eudes F (2008) Study of uptake of cell penetrating peptides and their cargoes in permeabilized wheat immature embryos. FEBS J 275: 2403-2414.

del Rio G, Castro-Obregon S, Rao R, Ellerby HM, Bredesen DE (2001) APAP, a sequence-pattern recognition approach identifies substance $\mathrm{P}$ as a potential apoptotic peptide. FEBS Lett 494: 213219.

Derossi D, Chassaing G, Prochiantz A (1998) Trojan peptides: the penetratin system for intracellular delivery. Trends Cell Biol 8: 84-87.

Dietrich FS, Voegeli S, Brachat S, Lerch A, Gates K, Steiner S, Mohr C, Pohlmann R, Luedi P, Choi S, Wing RA, Flavier A, Gaffney TD, Philippsen P (2004) The Ashbya gossypii genome as a tool for mapping the ancient Saccharomyces cerevisiae genome. Science 304: $304-307$.

Donadio S, Maffioli S, Monciardini P, Sosio M, Jabes D (2010) Antibiotic discovery in the twenty-first century: current trends and future perspectives. I Antibiot (Tokyo) 63: 423-430.

Dujon B, Sherman D, Fischer G, Durrens P, Casaregola S, Lafontaine I, De Montigny J, Marck C, Neuveglise C, Talla E, Goffard $\mathrm{N}$, Frangeul L, Aigle M, Anthouard V, Babour A, Barbe V, Barnay S, Blanchin S, Beckerich JM, Beyne E, Bleykasten C, Boistame 
A, Boyer J, Cattolico L, Confanioleri F, De Daruvar A, Despons L, Fabre E, Fairhead C, Ferry-Dumazet H, Groppi A, Hantraye F, Hennequin C, Jauniaux N, Joyet P, Kachouri R, Kerrest A, Koszul R, Lemaire M, Lesur I, Ma L, Muller H, Nicaud JM, Nikolski M, Oztas S, Ozier-Kalogeropoulos O, Pellenz S, Potier S, Richard GF, Straub ML, Suleau A, Swennen D, Tekaia F, Wesolowski-Louvel M, Westhof E, Wirth B, Zeniou-Meyer M, Zivanovic I, Bolotin-Fukuhara M, Thierry A, Bouchier C, Caudron B, Scarpelli C, Gaillardin C, Weissenbach J, Wincker P, Souciet JL (2004) Genome evolution in yeasts. Nature 430: 35-44.

Gautam A, Singh H, Tyagi A, Chaudhary K, Kumar R, Kapoor P, Raghava GP (2012) CPPsite: a curated database of cell penetrating peptides. Database (Oxford) 2012: bas015.

Gudmundsson GH, Lidholm DA, Asling B, Gan R, Boman HG (1991) The cecropin locus. Cloning and expression of a gene cluster encoding three antibacterial peptides in Hyalophora cecropia. J Biol Chem 266: 11510-11517.

Javadpour MM, Juban MM, Lo WC, Bishop SM, Alberty JB, Cowell SM, Becker CL, McLaughlin ML (1996) De novo antimicrobial peptides with low mammalian cell toxicity. J Med Chem 39: 3107-3113.

Juretić D, Vukicević D, Ilić N, Antcheva N, Tossi A (2009) Computational design of highly selective antimicrobial peptides. I Chem Inf Model 49: 2873-2882.

Kaneko T, Sato S, Kotani H, Tanaka A, Asamizu E, Nakamura Y, Miyajima N, Hirosawa M, Sugiura M, Sasamoto S, Kimura T, Hosouchi T, Matsuno A, Muraki A, Nakazaki N, Naruo K, Okumura S, Shimpo S, Takeuchi C, Wada T, Watanabe A, Yamada M, Yasuda M, Tabata S (1996) Sequence analysis of the genome of the unicellular cyanobacterium Synechocystis sp. strain PCC6803. II. Sequence determination of the entire genome and assignment of potential protein-coding regions. DNA Res 3: 109-136.

Klenk HP, Clayton RA, Tomb JF, White O, Nelson KE, Ketchum KA, Dodson RJ, Gwinn M, Hickey EK, Peterson JD, Richardson DL, Kerlavage AR, Graham DE, Kyrpides NC, Fleischmann RD, Quackenbush J, Lee NH, Sutton GG, Gill S, Kirkness EF, Dougherty BA, McKenney K, Adams MD, Loftus B, Peterson S, Reich CI, McNeil LK, Badger JH, Glodek A, Zhou L, Overbeek R, Gocayne JD, Weidman JF, McDonald L, Utterback T, Cotton MD, Spriggs T, Artiach P, Kaine BP, Sykes SM, Sadow PW, D'Andrea KP, Bowman C, Fujii C, Garland SA, Mason TM, Olsen GJ, Fraser CM, Smith HO, Woese CR, Venter JC (1997) The complete genome sequence of the hyperthermophilic, sulphate-reducing archaeon Archaeoglobus fulgidus. Nature 390: 364-370.

Lorenz D, Wiesner B, Zipper J, Winkler A, Krause E, Beyermann M, Lindau M, Bienert M (1998) Mechanism of peptide-induced mast cell degranulation: Translocation and patch-clamp studies. J Gen Physiol 112: 577-591.

Magrane M. and the UniProt consortium (2011) UniProt Knowledgebase: a hub of integrated protein data. Database bar009.

Mor A, Hani K, Nicolas P (1994) The vertebrate peptide antibiotics dermaseptins have overlapping structural features but target specific microorganisms. J Biol Chem 269: 31635-31641.

Jones P, Sivaloganathan S (2011) Computational and Mathematical Methods in Medicine. Comput Math Methods Med 2011: 303089.

Polanco C, Buhse T, Samaniego JL, Castañón-González JA (2013) Detection of selective antibacterial peptides by the Polarity Profile method. Acta Biochim Pol 60: 183-189.
Polanco C, Samaniego JL, Buhse T, Mosqueira FG, Negron-Mendoza A, Ramos-Bernal S, Castanon-Gonzalez JA (2012) Characterization of selective antibacterial peptides by polarity index. Int J Pept 2012: 585027.

Rana H (2011) Antimicrobial resistance: The current trend. Natl J Med Res 1: 22-23.

Sahr KE, Laurila P, Kotula L, Scarpa AL, Coupal E, Leto TL, Linnenbach AJ, Winkelmann JC, Speicher DW, Marchesi VT, Curtis PJ, Forget BG (1990) The complete cDNA and polypeptide sequences of human erythroid alpha-spectrin. J Biol Chem 265: 4434-4443.

Terry AS, Poulter L, Williams DH, Nutkins JC, Giovannini MG, Moore CH, Gibson BW (1988) The cDNA sequence coding for prepro-PGS (prepro-magainins) and aspects of the processing of this prepro-polypeptide. J Biol Chem 263: 5745-5751.

Thakur N, Qureshi A, Kumar M (2012) AVPpred: collection and prediction of highly effective antiviral peptides. Nucleic Acids Res W199204.

Umesono K, Inokuchi H, Shiki Y, Takeuchi M, Chang Z, Fukuzawa H, Kohchi T, Shirai H, Ohyama K, Ozeki H (1988) Structure and organization of Marchantia polymorpha chloroplast genome. II. Gene organization of the large single copy region from rps'12 to atpB. J Mol Biol 203: 299-331.

Vasconcelos AT, Ferreira HB, Bizarro CV, Bonatto SL, Carvalho MO, Pinto PM, Almeida DF, Almeida LG, Almeida R, Alves-Filho L, Assuncao EN, Azevedo VA, Bogo MR, Brigido MM, Brocchi M, Burity HA, Camargo AA, Camargo SS, Carepo MS, Carraro DM, de Mattos Cascardo JC, Castro LA, Cavalcanti G, Chemale G, Collevatti RG, Cunha CW, Dallagiovanna B, Dambros BP, Dellagostin OA, Falcao C, Fantinatti-Garboggini F, Felipe MS, Fiorentin L, Franco GR, Freitas NS, Frias D, Grangeiro TB, Grisard EC, Guimaraes CT, Hungria M, Jardim SN, Krieger MA, Laurino JP, Lima LF, Lopes MI, Loreto EL, Madeira HM, Manfio GP, Maranhao AQ, Martinkovics CT, Medeiros SR, Moreira MA, Neiva M, Ramalho-Neto CE, Nicolas MF, Oliveira SC, Paixao RF, Pedrosa FO, Pena SD, Pereira M, Pereira-Ferrari L, Piffer I, Pinto LS, Potrich DP, Salim AC, Santos FR, Schmitt R, Schneider MP, Schrank A, Schrank IS, Schuck AF, Seuanez HN, Silva DW, Silva R, Silva SC, Soares CM, Souza KR, Souza RC, Staats CC, Steffens MB, Teixeira SM, Urmenyi TP, Vainstein MH, Zuccherato LW, Simpson AJ, Zaha A (2005) Swine and poultry pathogens: the complete genome sequences of two strains of Mycoplasma byopneumoniae and a strain of Mycoplasma synoviae. J Bacteriol 187: 5568-5577.

Vlasak R, Unger-Ullmann C, Kreil G, Frischauf AM (1983) Nucleotide sequence of cloned cDNA coding for honeybee prepromelittin. Eur J Biochem 135: 123-126.

Wang G, Li X, Wang Z (2009) APD2: the updated antimicrobial peptide database and its application in peptide design. Nucleic Acids Res 37: D933-D937.

Wood ER, Matson SW (1989) The molecular cloning of the gene encoding the Escherichia coli $75-\mathrm{kDa}$ helicase and the determination of its nucleotide sequence and gentic map position. J Biol Chem 264: 8297-8303. 